\title{
Revus
}

Journal for Constitutional Theory and Philosophy of Law / Revija za ustavno teorijo in filozofijo prava

$37 \mid 2019$

Revus (2019) 37

\section{Legal normativity as a moral property}

\section{María Cristina Redondo}

URL: http://journals.openedition.org/revus/4825

DOI: 10.4000/revus.4825

ISSN: 1855-7112

\section{Publisher}

Klub Revus

\section{Electronic reference}

María Cristina Redondo, «Legal normativity as a moral property », Revus [Online], 37 | 2019, Online since 22 November 2018, connection on 27 May 2019. URL : http://journals.openedition.org/ revus/4825; DOI : 10.4000/revus.4825

This text was automatically generated on 27 May 2019

All rights reserved 


\title{
Legal normativity as a moral property
}

\author{
María Cristina Redondo
}

\section{Introduction}

1 Legal normativity is a very controversial subject that has been on the legal-philosophical agenda for a long time. Like many other crucial debates legal philosophy is concerned with, this one makes clear how contrasting philosophical conceptions bring about divergent interpretations and why it is really difficult to reach an agreement. Precisely for this reason, although we cannot aspire to reach a standard or a common explanation, we can and should struggle to gain larger and deeper understanding of the relevant premises that give rise to the disagreement.

2 This paper is a brief and sympathetic comment on some of the ideas that Brian Bix (2018) advances on this issue. Taking Kelsen's and Hart's contributions as a starting point, Bix tries to set the basis for a renewed analysis and advocates some general conceptual and substantive theses regarding the subject. I find his proposal particularly interesting because he chooses a fruitful path to address the problem. To be precise, Bix argues against two kinds of reductionism. On the one hand, a kind of empirical reductionism according to which legal normativity is nothing more than a causal contribution to obtain certain results. On the other hand, a kind of moral reductionism, according to which legal normativity is nothing more than a specific kind or case of moral normativity. The rejection of a sheer factual or moral approach is assumed throughout Bix's paper, and is explicitly stated in the following passage (Bix 2018: 36):

While many other theorists see little alternative to equating legal claims with either moral claims or predictions of official actions, I think the better view is that either equation is both unnecessary and unjustified.

3 According to this general thesis, legal normativity is not an empirical property. This does not mean that the law has no empirical features or empirical aims. In a contemporary cultural context, almost nobody denies that the law - each legal system - is a human 
construction. For this reason, it is possible to give an empirical, causal explanation about how legal normativity "emerges" or "exists" in our world. At the same time, nobody denies that legal norms aim at producing certain empirical results and avoiding others. In other words, one of its purposes is to have causal relevance in motivating behaviour. Nevertheless, when we say that the law has a normative claim, or that it is normative, we are not referring to these empirical features related to its genesis or some of its functions. We are saying that that the law has an evaluative or justificatory claim as well. One of the paradigmatic aims of the law is to create duties, prohibitions, and permissions and we cannot capture, or at least we cannot exhaust the meaning of, this normative feature through any empirical explanation. We can understand the concept of legal normativity only by appealing to other normative concepts.

4 The second general idea that seems to be implied in the quoted passage is that legal normativity is a relatively autonomous concept. Chiefly, legal normativity is not a specific kind of moral normativity and, a fortiori, it is not synonymous with moral normativity. To grasp the concept of legal normativity it would be useful to compare it to other related concepts, for instance, moral normativity. But, if I understand Bix correctly, this exercise does not imply that we are looking for a unified concept of normativity or a fundamental kind legal normativity is subordinated to. My comment will focus on this second set of ideas. On this topic, I think that Bix's paper must be celebrated for highlighting the nonreductionist thesis: legal normativity neither means, nor implies, moral normativity.

Nevertheless, I will advance some criticisms of Bix's presentation. First, it must be said that there is a tension in Bix's analysis. Although he explicitly supports a non-moralist conceptual thesis, he does not seem to assume some of the conceptual commitments that follow from it. The core of my comment aims to show this tension. Second, Bix does not clearly distinguish the conceptual question regarding what 'legal normativity' means from the different question regarding whether normativity is, or is not, a necessary feature of the law. This is in itself regrettable. In any case, Bix mainly focuses on the latter topic and endorses the vision of some authors who support a "new view" in legal theory. These authors emphasize that legal systems are not necessarily, or not always, normative. The problem is that they reject that the law is necessarily normative (or that it necessarily aims at being normative) precisely because they presuppose that normativity is a moral property. That is to say, they assume the moralist conceptual thesis that (apparently) Bix is trying to reject. Finally, as we have seen in the cited passage, Bix defends a negative thesis regarding what legal normativity is not. Having admitted that it is neither an empirical nor a moral property, the big question is, what does legal normativity mean? It would have been interesting to know more about how Bix understands legal normativity. In this regard, I will submit some brief considerations that support the non-moralist understanding of legal normativity. Certainly, I do not think these considerations are decisive. My purpose is to stress that some positivist legal theorists not only offer different explanations of legal normativity (e.g. Kelsen and Hart), but actually disagree (though not always explicitly) on what 'legal normativity' means. The only way to proceed in this debate is to make explicit the underlying reasons for these contrasting understandings and the theses each understanding is committed to. 


\section{The concept and the explanation of legal normativity}

6 To provide an account of legal normativity, two important questions have to be distinguished: a) What does it mean that law is normative? b) How do legal theorists (Kelsen, Hart, or any other) explain the normativity of a legal system? Bix (2018: 40) seems to see clearly this distinction when he states:

Stanley Paulson wrote: “Exactly what 'normative' comes to in Kelsen's Pure Theory of Law has never been clear". One might make a similar claim about many contemporary legal theorists: they purport to "explain legal normativity", but often fail to articulate what it means to say that law is normative or in what way that property requires explanation.

7 The question about the concept of legal normativity and the question about what the (best) explanation of legal normativity is are different. Bix reminds us of two well-known positivist legal theories that offer two different explanations of legal normativity. According to Bix, Hans Kelsen explains it by appealing to the presupposition of a nonpositive Basic Norm while Herbert Hart explains it on the basis of the adoption of an internal point of view regarding a basic customary rule. Both Kelsen's and Hart's explanations are sophisticated and we would need to introduce a precise set of concepts in order to present them properly. Although I will raise some doubts regarding Bix's reading of Kelsen's proposal, I will assume that he is right about how Kelsen and Hart explain legal normativity.

Despite their different explanatory proposals, Kelsen and Hart - along with many other philosophers - share some basic ideas regarding normativity. A normative content is a binding content. If a regulative norm exists, a behaviour is no longer optional. ${ }^{1}$ Using a language introduced by Herbert Hart that produced a turning point in legal theory, normativity can be understood in terms of justificatory reasons for action. There are different kinds of reasons and norms, and the law is one of them. Although Kelsen did not use this language, he would accept that if something is normative it binds behaviour. ${ }^{2}$ The relevant point here is that Kelsen and Hart can coherently assert that normativity is one of the essential features of every legal system precisely because they clearly distinguish legal normativity form moral normativity. By asserting that the law is normative, they are not attributing any moral property to it. Legal normativity does not constitute nor imply moral normativity.

9 Given that this basic thesis is generally rejected in contemporary legal philosophy, it is important to stress that Kelsen and Hart agree on it. According to a post-Hartian approach, legal normativity is conceptually linked to morality. Legal requirements are "fully" normative only to the extent that they provide or trigger moral reasons. This conceptual move is highly significant. On the one hand, it is connected to what we can call the "the unity of practical concepts". On the other hand, it is connected to what Carlos Nino has called "morality's imperialism". ${ }^{3}$ In brief, according to this post-Hartian view, morality is no longer seen as just another system of norms parallel to those formed by legal, religious, or etiquette norms. Instead, even it leads to paradoxical results; morality is conceived as the only kind of genuinely normative requirement. Moral reasons are defined as those reasons that apply to all of us, and the only ones able to justify actions and decisions that go beyond our self-interests. Consequentially, any 
normative or justificatory content, which is not a sheer prudential reason, constitutes (or implies) a moral reason.

Bix correctly expresses this idea when he mentions John Gardner's analysis of morality. He reminds us that: "According to Gardner, one cannot reasonably ask whether one should follow the dictates of morality. But one can reasonably ask that question of law" (Bix 2018: 30). In this perspective, whoever asks whether morality constitutes reasons for action does not well understand what morality means. From Gardner's point of view, the law necessarily aims to be normative and if it succeeds, it is morally relevant, i.e. it will affect what we are morally justified to do. In a nutshell, when we talk of moral and legal normativity within this approach, we are talking of the same kind of property. We are a) presupposing a common concept of normativity and b) assuming that normativity is a moral property. Let me call these two ideas "the moralist conceptual thesis". ${ }^{4}$

11 It is extremely interesting to note that this moralist conceptual thesis is largely accepted by contemporary positivist theorists. On the one hand, it is accepted by realist or sceptic positivists. This is why they reject the idea that legal theory has to concentrate its efforts on analysing legal normativity. According to this position, normative claims are the expression of subjective moral preferences. Legal theory has to focus its research on the objective, empirical features of the law, and this enquiry must be done through a scientific methodology. On the other hand, the moralist conceptual thesis is generally accepted among Anglo-Saxon legal philosophers. Joseph Raz has been highly influential on this point. Raz fully embraces the Hartian idea according to which the normative claims of the law can be fruitfully understood in terms of reasons for action. The law does not only aim at creating prudential reasons through sanctions, it also purports to constitute a specific kind of normative reason. Nevertheless, at the same time, Raz deeply disagrees with Hart about the reasons that every legal system aims at providing. In Raz's view, the law necessarily aims at being normative, i.e. aims at creating duties and at being binding. However, the law is normative (if it really is) in the same sense that morality is normative. If the law succeeds in creating duties, these are duties in the same sense in which we have moral duties. ${ }^{5}$ Consequently, the concept of law - at least one of its essential properties - cannot be understood without appealing to morality. There is a necessary connection between the concept of law and the concept of moral reason.

I think it is important to stress this conceptual disagreement between Kelsen and Hart on the one hand, and Raz and post-Hartian scholars on the other. Otherwise, we could not make sense of the Razian proposal according to which, in order to identify legal norms and duties, a legal theorist needs to assume a detached point of view. Detachment - it is assumed - is moral detachment. ${ }^{6}$ However, if the moralist concept of normativity is not assumed, a positivist legal theorist does not need a morally detached point of view to identify legal norms.

Bix (2018: 30) correctly asserts that according to Kelsen, accepting or seeing normativity in our (natural, empirical) world is just the result of a possible reading that some of us have of certain events: "Other equally competent and intelligent adults can look at the same world and see nothing normative". In Bix's (2018: 30) view:

This reading of Kelsen and normativity is related to Joseph Raz's helpful idea of "detached normative statements". Raz's basic idea is that one can speak of what a normative rule or system requires, without necessarily endorsing or accepting that rule or system. Thus, someone who is not a vegetarian can say to a vegetarian friend, "you should not eat that (because it has meat in its ingredients)" [...] Analogously, the radical lawyer or anarchist scholar can make claims about what 
one ought to do if one accepted the legal system (viewed the actions of legal officials in a normative way), even if that lawyer or scholar saw the actions of legal officials only in a non-normative way, as mere acts of power.

14 The suggestion that Raz's proposal regarding a morally detached point of view can be useful to express Kelsen's idea of legal normativity is very surprising. It is surprising because it strongly suggests that we have already assumed that Kelsen's concept of legal normativity amounts to, or implies, moral relevance. In other words, we are assuming that Kelsen and Raz understand normativity in the same way, i.e. as a moral property. The question is: Is it appropriate to understand that, according to Kelsen, reading the actions of legal officials "in a normative way" is to ascribe moral relevance to them? Is this moral reading the only alternative to seeing sheer acts of power? If we accept the moralist conceptual thesis the answer is: Yes, it is the only alternative. Every normative or justificatory consideration that is not a prudential reason is a moral reason.

Setting aside the critical point regarding whether it is licit to read Kelsen's theory through Razian eyes, the goal of this first comment is to emphasize that there is a tension in Bix's analysis. If I understand him well, the view that Bix is trying to support rejects the moralist conceptual thesis. We need not accept that there is only one concept of normativity - a moral one. Although they are closely related, we can and should distinguish moral from legal normativity. Shortly, if we really think that equating legal claims with moral claims is both unnecessary and unjustified, then we must openly reject Joseph Raz's and the post-Hartian understanding of the legal ought and legal normativity. This is because according to the latter approach, legal normative claims are moral claims.

\section{Are legal systems normative systems?}

The conceptual question regarding what legal normativity means must also be distinguished from the question regarding whether normativity is a necessary or a contingent property of legal systems. According to Bix (2018: 39):

\footnotetext{
One might reasonably question whether we (whoever "we" might be in this case) do in fact believe that legal norms "provide [us] with special reasons for acting", separate from the prudential reasons associated with legal sanctions, or the general moral reasons that some legal norms might sometimes trigger. Additionally, even if a significant number of people believe that law qua law gives them reasons for action, this may be a matter calling more for a psychological or sociological explanation, rather than a philosophical one.
}

In Bix's view, legal philosophy should not be especially interested in explaining legal normativity because it is not a necessary feature of law. In this way, Bix distances himself from the standard position in current legal theory and sides in favour of a "new view": legal systems are not always normative systems.

On this basis, Bix disagrees with both Kelsen and Hart. This is because from these authors' point of view, legal philosophy must explain the normative character of the law precisely because it is one of its essential features. To be sure, Kelsen and Hart do not endorse the moralist conceptual thesis. Whoever endorses the separability thesis would contradict themselves if they accepted that the law is necessarily normative and that normativity is a moral property.

19 As we have seen, Bix also seems to resist the moralist conceptual thesis, which is largely shared in current legal theory. Legal normativity does not amount to - nor imply - a 
moral property. However, rejecting the moralist concept of normativity has a price, which Kelsen and Hart clearly accept, but Bix is not willing to pay. By accepting that something can be normative (i.e. can constitute a justificatory reason) without being a moral reason or having moral relevance, you have to reject an idea the force of which Bix finds difficult to resist. This is the idea that reasons are reducible to either prudential or moral reasons. This is because it implies that in order to have genuine (not sheer prudential) justificatory power, a reason must be moral. In other words, it implies what Carlos Nino has called "morality's imperialism".

Normative power means justificatory power. When we accept a moralist conception of normativity, we must accept a moralist conception of justificatory reason as well. The current position in legal philosophy is coherent. Normativity is analysed in terms of justificatory reasons, and both concepts are moral. If the law is normative, it is a kind of moral reason or it has moral relevance, i.e. it triggers moral reasons. By contrast, Bix's position is ambivalent. As we have seen, according to Bix, equating legal claims with moral claims is both unnecessary and unjustified. On this basis, he seems to assume a non-moralist concept of normativity. That said, this position implies that moral reasons are not the only kind of normative reasons. To be precise, it implies that along with moral reasons there can be legal, political, religious, etiquette, or fashion reasons. However, Bix (2018: 35$)$ refuses this position and asserts:

There is, to be sure, something a little strange about this line of analysis - one can understand the force of the objection that "legal reasons" should reduce either to prudential reasons, on one hand, or moral reasons, on the other.

21 At the end of the day, law's normative claims are either prudential or moral claims. Tertium non datur. Legal reasons - that cannot be fully understood in terms of the prudential interest in avoiding sanctions - must be understood as moral reasons. There is no other possibility.

Consequently, having admitted this, Bix subscribes to what he considers a "new view" in legal theory. According to this view, normativity is not a necessary or conceptual feature of law. This position is an entirely coherent one. In fact - it should be stressed -, it is the only coherent position for a positivist legal theorist. When a positivist accepts that the law's normativity is a moral property, she is constrained to either abandon the separability thesis or to maintain that the law is not necessarily normative. In other words, once a positivist legal theorist rejects the conceptual premises on which classical positivists like Kelsen and Hart have based their theories, the "new view" becomes obligatory.

Unfortunately, Bix does not discuss the two premises the "new view" is based on. That is, on the one hand, the idea that we do share a unified concept of normativity (a unified concept of ought and reasons for action), or on the other hand, the idea that this unified concept is a moral one. In other words, what I have called "the moralist conceptual thesis". Bix assumes these theses are sound. In this regard, I must confess a preference for Bix's first line of argumentation, where he asserts that the moral understanding of normativity is neither necessary nor justified. In my view, it is a much more fruitful path to follow and constitutes a more realist stand. It takes seriously several distinctions we accept as a matter of fact: First of all, the fact that we admit different kinds of norms and duties that are not based on a single, fundamental one; Secondly, the fact that in our current understanding and language, the law is conceived as a normative institution. It is highly perplexing and misleading to say that legal norms are not normative or that they 
do not necessarily purport to be genuine norms. What does this mean? The only way to make sense of this distortion is to explain that, against our usual understanding, there is a strong tendency among moral and legal philosophers according to which only moral reasons are genuine reasons. So, in order to be normative, the law has to have moral relevance. It is not only a matter of language and words' meanings. The point is that, as Bix initially recognizes, this position does not seem necessary and, above all, it is not justified.

By abandoning this line of thought, Bix is constrained to disagree with Kelsen and Hart. It is true that many of these authors' ideas deserve to be criticized. However, I would not include among them the idea that legal orders are normative orders, or at least that they necessarily purport to be normative. To be sure, they are not saying that, for this reason, legal systems necessarily aim at creating or triggering moral reasons. Actually, it is not difficult to express these two ideas: a) the law necessarily aims at guiding behaviour and providing justificatory reasons, but $b$ ) it does not necessarily aim at having moral relevance. These are two different questions that only the assumption of a moralist unified concept of justificatory reason and normativity makes us conflate.

By stressing the normativity of law as one of its essential features, Kelsen and Hart made a relevant point, even if they may have failed to provide an appropriate explanation of it. However, positivist legal theory has the conceptual instruments to face this issue without renouncing the thesis that these authors were trying to sustain against those who reduce the law to a sheer empirical fact: legal orders are normative institutions. Surely, if we say that the law is a normative phenomenon (non-reducible to empirical facts) and, at the same time, that it is only contingently connected to morality, we are implying that its normativity is not a moral property. The challenge for this kind of "normativist" legal positivism is to give a more precise analysis of what this - non- empirical and non-moral - property means and how it is explained within a positivist framework.

\section{Some concluding remarks} support the same conclusion that Kelsen and Hart were trying to defend: the law is a normative phenomenon and its normativity is not necessarily connected to moral normativity.

order to support this conclusion, it is important to keep in mind a basic premise. If we accept "the moralist conceptual thesis" we cannot go further. Assuming a moralist concept of normativity, at the end of the day, all norms and duties will be of the same kind: moral reasons. In other words, we have to accept the possibility that along with moral justificatory reasons, there exist aesthetic, political, legal justificatory reasons. That is, when we refer to legal and moral reasons we are not talking of the same kind of reasons. Only under this presupposition, will the moral character (or moral relevance) of legal reasons not be conceptually presupposed.

When we have accepted that legal reasons can be authentic reasons, one of the crucial bases for concluding that legal reasons must be moral reasons collapses, namely, the accepted prudential-moral dichotomy. In effect, a common argument according to which legal reasons must be moral in nature is the fact that legal norms aim at imposing duties to third parties and claim the right to grant rights to others. It is largely admitted that 
prudential reasons alone cannot do this work. Therefore, in order to do what they intend to do, legal norms need to be (or to be based on) moral reasons. However, once one has already accepted the possibility that legal reasons are authentic reasons capable of justifying the authoritative imposition of duties, one could not invoke the prudentialmoral dichotomy to conclude that legal reasons must be, or must be based on, moral reasons. We need to say something more about this.

The way to proceed in this discussion is to make explicit what makes a reason a moral or a legal reason. After that, we will be able to determine whether they share some essential properties or significantly differ from each other. In this context, it is not possible to offer the conscientious analysis that this point deserves. Nevertheless, let me recall some of the well-known necessary features of every moral reason. First, it has been stressed that moral reasons are inescapably binding on us. In other words, it would be conceptually odd to say that something is a moral reason, but is not practically relevant. If this is a mark of moral reasons, however, then we can be sure that legal and moral reasons differ significantly. It is not necessary to stress that legal reasons are not inescapable. Even Hobbes came to admit their inapplicability in the extreme cases in which our survival is at stake. Second, it is usually admitted that moral norms and reasons are universally valid. They are inescapably binding on all of us. There are disagreements about the universal scope of morality. However, if bindingness on every human being is an essential trait of morality, it is a feature that morality does not share with the law. Third, and most importantly, moral norms and reasons are explained as those whose validity is independent from our beliefs and desires. It is part of our understanding of morality that, in this sense, a moral requirement is 'objective'. Stated differently, whether it is true that acting in a certain way is morally justified, it is true independently of our beliefs or attitudes. In this sense, it should be clear that when we talk of moral reasons we are talking of "critical morality" and not of "positive morality".

This latter feature deserves a brief reflection. On this point, we can think that the law is similar to morality. In a certain sense, legal norms and reasons are objective as well. This does not mean, however, that their existence and content are independent from our beliefs and desires. On the contrary, it is almost unanimously acknowledged that legal norms and reasons are a human construction. They are part of a formal, institutional world. As John Searle puts it, even though we can have objective knowledge of it, institutional reality is ontologically subjective ${ }^{8}-$ it depends on us.

In any case, many legal norms apply to us independently of our will. In this sense, they present categorical - not hypothetical - demands. This point invites us to return to Bix's interpretation of Kelsen's Basic Norm. Kelsen explains the normativity of the law through the presupposition of a hypothetical Basic Norm. We could decide to close our eyes to any legal normative reality. It is in our hands to read the empirical facts as bringing about norms: permissions, prohibitions, and duties. The relevant point in this case is that through this presupposition, Kelsen is trying to explain the same thing that Hart is trying to explain when he says that the simple Austinian scheme of habits and orders is not enough to give an adequate account of the law. For instance, it is not sufficient to explain how a new legislator already has the right to legislate even when a habit to obedience does not yet exist. ${ }^{9}$ It is also insufficient for the understanding of the notion of obligation or duty. ${ }^{10}$ In order to explain these crucial aspects of the law we need the concept of rule. In other words, the law cannot be explained through a simple scheme of habits, orders, and threats because it is a normative object. However, the fact that it is so ultimately 
rests on human attitudes. Having said so, both Kelsen and Hart would accept that, as Leslie Green asserts, "the law makes categorical demands upon citizens". ${ }^{11}$ What is hypothetical for Kelsen is the Basic Norm, not the positive norms the law consists in. Once one has presupposed the hypothetical Basic Norm, one sees legal norms and, among them, categorical and hypothetical demands. In any case, the fact that the law makes categorical demands upon citizens does not imply that they are moral in nature. As I have tried to show, categorical legal demands on citizens differ significantly from categorical moral demands: a) they are not inescapable, b) they are certainly non-universal, and above all, unlike moral demands, c) their existence, validity, and content are entirely based on our believes and attitudes. In sum, like moral norms, legal norms may be categorical demands. However, they are explicable and justifiable on entirely different bases. As I have said earlier, I am not trying to suggest that these considerations constitute an accurate analysis. The only point I would like to suggest is that, if we want to maintain that the normativity of the law does not imply nor amount to a moral property, we must reject the post-positivist analysis and make explicit what the relevant differences between these properties are. In other words, in the current philosophical context, a position like this has the burden of the proof - it must justify why legal normativity is not reducible or subordinated to moral normativity.

Bix did not offer an explicit reflection on the concept of moral and legal normativity. The only thing we know is that, in Bix's view, legal normativity is neither an empirical nor a moral property. A deeper analysis would have allowed us to better understand what justifies his conclusion that normativity is only a contingent, non-essential property of legal systems. In other words, to understand why he disagrees with Kelsen and Hart. The suspicion is that Bix's conclusion is based on the same conceptual presupposition that the supporters of the "new view" assume. That is to say, the idea that normativity is, or at least implies, a moral property. This doubt remains. In any case, Bix (2018: 36) clearly sees the point when he says:

Ultimately, the question is whether it is productive - or, on the contrary, absurd to think that reasoning is often confined within a particular domain: that one can have "legal reasons" that can differ from not only "moral reasons" and "prudential reasons", but also "etiquette reasons", "fashion reasons", or "chess reasons".

зз I think it would be wise to openly discuss this deep disagreement between positivist legal theorists. Apparently, Joseph Raz has only enriched Hart's conception of law as a set of norms analysed in terms of reasons for action. However, as a matter of fact, Raz has overturned the Hartian conception of the normativity of law. When we accept Razian ideas about the unified moral concept of ought, we have no alternative to saying that the law is only sometimes normative. If we take distance for a moment from this statement it sounds quite shocking. However, while legal positivists do not directly face the already presupposed "morality's imperialism", the only coherent position to adopt is a rejection of Kelsen's and Hart's insights and denial that legal systems are essentially normative systems. On the contrary, when a legal positivist thinks that normativity is a defining property of legal systems that should not be reduced to an empirical or a moral property, by the same token she is committed to rejecting the moralist conceptual thesis and has to provide an appropriate analysis of what this property precisely means. 


\section{BIBLIOGRAPHY}

Brian BIX, 2018: Kelsen, Hart, and Legal Normativity. Revus. Journal for constitutional theory and philosophy of law (2018) 34. 25-42. URL: https://journals.openedition.org/revus/3984.

Herbert L. A. HART, 1963: The Enforcement of Morality. Law, Liberty, and Morality. Stanford, CA: Stanford University Press.

Herbert L. A. HART, 1961: The Concept of Law. Oxford: Clarendon Press.

Herbert L. A. HART, 1982: Essays on Bentham. Studies on Jurisprudence and Political Theory. Oxford: Clarendon Press.

Hans KELSEN, 1992: Introduction to the Problems of Legal Theory (1934). New York: Clarendon Press.

Carlos S. NINO, 1989: El constructivismo ético. Madrid: Centro de Estudios Constitucionales.

Carlos S. NINO, 1994. Derecho, Moral y Política. Una revisión de la teoría general del derecho. Barcelona: Ariel.

Joseph RAZ, 1975: Practical Reason and Norms. London: Hutchinson.

Joseph RAZ, 1979: The Authority of Law. Oxford: Clarendon Press.

Joseph RAZ, 1980: The Concept of Legal System. $2^{\text {nd }}$ ed. Oxford: Clarendon Press.

John SEARLE, 1995: The Construction of Social Reality. London: Penguin Books.

\section{NOTES}

1. Cf. Hart 1961: 79-88.

2. Cf. Kelsen 1992 (1934): 42-43.

3. According to the first idea, normative terms like "a right", "a duty", "ought" have the same meaning in legal, moral, and other normative contexts. See Raz 1979: 158-159. According to the second idea, this unified meaning is a moral meaning. Regarding the idea of 'morality's imperialism' see Nino 1994: 82 . This proposal implies the necessary justificatory connection between law and morality. That is to say, the law succeeds in justifying behaviour only if it is based on moral considerations. See Nino 1989: 30, 114-115.

4. Apparently, authors subscribing to this moralist conceptual thesis regarding normativity distinguish two kinds of norms: legal and moral. However, they deprive legal norms of any capacity to justify behaviour unless they are either identical to moral norms or based on them. In this sense, legal norms are conceived of as sheer facts, having no justificatory power unless they are connected to morality. Cf. Nino 1989: 30 and 115.

5. Hart (1982: 147) has explicitly contested this approach.

6. Cf. Raz 1975: 170-1777. See also, Raz 1980: 234-238.

7. Regarding the distinction between critical and positive morality, see Hart 1963: 20.

8. Cf. Searle 1995: 7-13.

9. Cf. Hart 1961: 50-64.

10. Cf. Hart 1961: 79-84.

11. See Bix 2018: 37. 


\section{ABSTRACTS}

This paper comments on Brian Bix's article "Kelsen, Hart, and Legal Normativity". It provides some remarks regarding the concept of normativity and subscribes to the idea that it should not be reduced to an empirical nor a moral property. The discussion is primarily focused on the current, post-Hartian thesis that reduces legal normativity to moral normativity. In this regard, on the one hand, it advances a criticism of Bix's analysis, which at first glance rejects both forms of reductionism but, at the end of the day accepts a post-Hartian approach that treats normativity as a moral property. On the other hand, it highlights that this moralist concept of normativity is primarily based on the assumption that normative terms have a unified meaning in moral and legal contexts and that, according to that meaning, normativity is a moral property. The proposal is that within a positivist approach, it is necessary to discuss these assumptions in order to give an adequate account of legal normativity as an essential property of every legal system.

\section{INDEX}

Keywords: legal normativity, moral normativity, morality's imperialism, legal positivism

\section{AUTHOR}

\section{MARÍA CRISTINA REDONDO}

Professor of legal philosophy, Tarello Institute for Legal Philosophy, Law Department, University of Genoa (Italy).

Address: Tarello Institute for Legal Philosophy - Via Balbi 30/18 - 16126 Genova - Italia.

E-mail: cristina.redondo [at] unige.it 